\title{
SCALE OF POLLUTIONS WITH HEAVY METALS IN WATER AND SEDIMENT OF RIVER IBËR FROM LANDFILL IN KELMEND, KOSOVO
}

\author{
Sadija KADRIU*, Milaim SADIKU, Mensur KELMENDI, \\ Ismet MULLIQI, Mehush ALIU, Arbër HYSENI \\ Department of Technology, University of Mitrovica, "Isa Boletini” 40000, Mitrovica, Kosovo
}

\begin{abstract}
Pollution with heavy metals and waters in Mitrovica with surroundings, both in the past and in present days, is a preoccupation for the citizens of Mirtovica, as well as for the other inhabitants living around it. Such a problem has been a concern which still continues for a number of researchers who have been dealing with this issue, and who still continue to be preoccupied with the issue of heavy metal (habitat) pollution in this part of Kosovo. Heavy metal's contamination of the environment's main components, dates back to the $1970 \mathrm{~s} / 90$ s to this date. This pollution, especially of the rivers, is due to the industrial activity taking place in the Trepça Combine and the presence of industrial landfill sites of this Combine near the flow of two main rivers: the Sitnica and Ibër River waters, in the city of Mitrovica. The focus of our study, this time consists solely in the research and illumination of pollution with these heavy metals and waterworks of the Ibër River, as a result of the pollution caused by the industrial waste landfill located in Kelmend village. In the paper, we have attempted to show the concentration of heavy metals in sediment and water, by pointing at four sample sites of the Ibër river: in the Bosniak $U_{1}$ neighborhood, then in the flow in front the $\mathrm{U}_{2}$ landfill, discharge flows from landfill $\mathrm{U}_{3}$ and a certain distance from the $\mathrm{U}_{4}$ landfill.
\end{abstract}

Keywords: river, waters, sediments, heavy metals

\section{INTRODUCTION}

The heavy metal pollution dates back to the 30 s of the last century, when the foundations of the Trepça Combine were established and at the same time exploitation of $\mathrm{Pb}$

\footnotetext{
* Corresponding author: sadija.kadriu@umib.net (S. Kadriu)
}

doi: $10.37190 / \mathrm{msc} 192610$ 
$\mathrm{Zn}$ and other minerals began. Exploitation and processing of minerals, apart from economic development, resulted in the pollution of the environment (air, water and soil) with heavy metals, not only in Mitrovica, but also beyond. Therefore, before the structures of this Combin, it emerged as the need for the creation of landfills for industrial waste disposal in three designated locations in the Mitrovica district. In addition to the landfills established in Shupkove and Zvecan, the other landfill that makes the Ibar River contamination and which is the object of our study, is located in the village of Kelmend, near the Ibar River waters.

The background of the formation of Kelmendi's landfill, dates back to 1968, while the industrial waste disposal has taken place since 1975 and has continued to this day.

The use and exploitation of ore from the Trepça mine in Stari Tërg, and its processing in the First Tunnel flotation, resulted in the dumping of industrial waste at Kelmendi Landfill. The continued existence of this landfill near the waters of Ibër River, and the discharge of wastewater contaminated with heavy metals from this landfill to the Ibër River waters through the so-called Zharkov Potok creek, caused heavy water pollution and sedimentation of this river.

The Kelmend landfill lies in a $2-3 \mathrm{~km}$ area and is located between two hills in the northeastern part of Mitrovica. On the west side of the landfill, at the bottom, there is a torrent that is known in the topographic map Zharkov Potok and through it the pollutants are poured into the Ibër River.

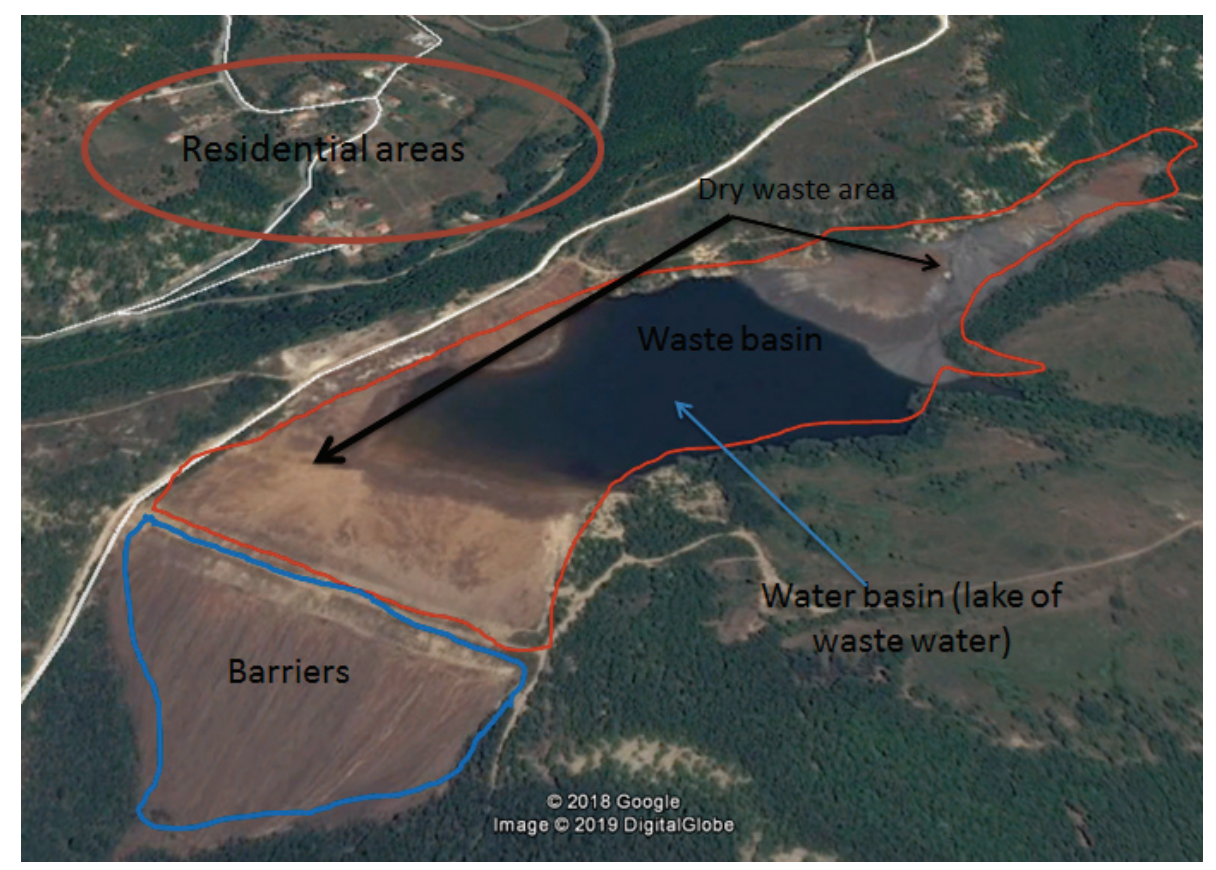

Fig. 1. Proportion of Kelmendi landfille (www.gjeoportal-ks.gov) 
This landfill is still active and with capacity of depositing 8.2 million cubic meters in an area of 18.4 ha with industrial waste.

The material is transported from the flotation to the landfill through conveyor pipes. In the central part of the landfill is precipitated lake (see Fig. 1). The composition of waste (skewer) is different and depends from the composition of the ore. The waters that drain from the landfill and the landfill's lake, flow to the Ibër River through the drainage of the landfill, without any prior treatment. In order to reduce the possibility of erosion and the suspension of airborne particles caused by the winds approaching the landfill, only one part of the landfill has been cultivated. However, the uncultivated part, specifically, the surface of the dam, is white and the wind rises the dust, which almost covers Mitrovica and some villages in its vicinity.

For the transfer of water caused by atmospheric rainfall, there are builted two concrete canals, located between 100 and 200 meters in length of the dam, which prevent water penetration in the direction of the dam, preventing the possible erosion on the screen of the dam.

The composition of the deposited wastes, as we say above, varies, while the clear water, which carries heavy metals, from the lake of the landfill, through the collector and stream, Zharkov Potok, flows into the waters of the Ibër River. For years, no one has taken care for the revitalization of the landfill and as such, it poses a potential risk not only for the pollution of groundwater and heavy metals, but also the pollution of the environment as a whole (Kadriu et al. 2011).

According to Dauvalter and Rognerud, heavy metals penetrates into the hydrosphere from natural and anthropogenic sources. Some of the anthropogenic resources are: the industrial waste industry, the existence of mines, the melting of the ore, and the existence of different landfills (Dauvalter, Rognerud 2001). The heavy metals in the water are quickly dissolved and then are being thinned at the bottom of the river bed as carbonates, sulfates and sulfides which are less soluble (Goletić 2005). Chehregani and Malayer have reported that high concentrations of heavy metals have strong toxic effects and are considered as potential environmental pollutants (Chehregani, Malayeri 2007). One of the most disturbing concern which is present in the past few years and which preoccupies humanity, is the issue of heavy metal contamination of aquatic environments since these metals cannot be dissolved, and most of them have toxic effects on living organisms (MacFarlane et al. 2000). Recently, anthropogenic activities have steadily increased the amount of heavy metals in aquatic ecosystems, and by this, the heavy metal pollution in the water system is growing at an alarming rate and has become an important problem around the world (Malik et al. 2010) while trace elements have enhanced environmental impact due to their use in human life (Chintan Pathak, Hiren C. Mandalia 2011).

For this reason, in this study, our focus is determination of the level of pollution with heavy metals $\mathrm{Pb}, \mathrm{Zn}, \mathrm{Cd}, \mathrm{Hg}, \mathrm{Cu}, \mathrm{Mn}$ and $\mathrm{Sb}$ of Waters and Ibër ian sediment during the summer and winter 2018/2019. 


\section{MATERIAL AND METHODS}

Based on the Directive Wsater Surface Monitoring, we have established a monitoring network in order to ensure that the results of the water quality assessment are accurately as possible.

The monitoring network includes four monitoring points (tab.1) in the waters of the Bosniak $U_{1}$ neighborhood, then the water flow in front of the landfill just after joining with Sitnica River $\mathrm{U}_{2}$, at the discharge stream from the landfill of Zharkov Potok $\mathrm{U}_{3}$ landfill site and at a certain distance after the landfill following the spillage of Zharkov Potok. In the $\mathrm{U}_{4}$ monitoring point, except in the water, the concentration of heavy metals was also analyzed in the sediment as well, because of the fact that the $\mathrm{U}_{4}$ location is located downstream of heavy metals contaminated with wastewater from Kelmendi landfill. The samples taken for each monitoring point, except for sediment, were made during the summer and winter season of 2018/2019.

Table 1. Sampling points and their coordinates

\begin{tabular}{|l|l|c|c|c|}
\hline \multicolumn{1}{|c|}{ River } & \multicolumn{1}{|c|}{ Location } & $\begin{array}{c}\text { Geographical } \\
\text { width }\end{array}$ & $\begin{array}{c}\text { Geographical } \\
\text { length }\end{array}$ & $\begin{array}{c}\text { Altitude } \\
(\mathrm{m})\end{array}$ \\
\hline Ibër $\mathrm{U}_{1}$ & At the Bosniak Neighborhood & $42^{\circ} 53^{\prime} 41.98^{\prime \prime}$ & $20^{\circ} 52^{\prime} 19.46^{\prime \prime}$ & 502 \\
\hline Ibër $\mathrm{U}_{2}$ & After joining with Sitnicë River & $42^{\circ} 54^{\prime} 9.72^{\prime \prime}$ & $20^{\circ} 52^{\prime} 15.02^{\prime \prime}$ & 497 \\
\hline $\begin{array}{l}\text { Zharkov } \\
\text { Potok } \mathrm{U}_{3}\end{array}$ & $\begin{array}{l}\text { Ibër-Kelmend } \\
\text { at the Zharkov Potok }\end{array}$ & $42^{\circ} 54^{\prime} 11.54^{\prime \prime}$ & $20^{\circ} 52^{\prime} 17.03^{\prime \prime}$ & 502 \\
\hline Ibër $\mathrm{U}_{4}$ & $\begin{array}{l}\text { Ibër- Kelmend, after sillage } \\
\text { of Zharkov Potok creek }\end{array}$ & $42^{\circ} 54^{\prime} 10.53^{\prime \prime}$ & $20^{\circ} 52^{\prime} 18.89^{\prime \prime}$ & 501 \\
\hline
\end{tabular}

The method of sampling, the quantity of the sample collected and the mode of transport and the maximum period that samples can resist prior to chemical analysis, are performed in accordance with paragraph 5.4 of EN ISO/CEI 17025 (International Standard 17025; 2005).

The water sample is placed in a glass bottle or polyethylene previously cleansed with hydrochloric acid and rinsed with distilled water, and finally the container is sealed. The sample is taken between the water flow and at different depths. The volume of the sample taken is $1 \mathrm{dm}^{3}$, their conservation is done in accordance with the American Public Health Association conservation procedure, 2005 (APHA 2005).

All sediment samples, according to the procedure, should be placed in special containers. The sample is handled with the help of a special equipment, which is designed for sampling of sediment and from the bottom layer of the river bed as well. At least $1000 \mathrm{~g}$ sample is taken and placed in a polyethylene container. To prevent them from being contaminated, the environment where the sample is prepared shall be cleaned. Moisted sediment and waste cannot be a representative sample. In order to b repre- 
sentative sample, the sediment should dry out in room temperature. Then, the dry sample is crushed in the spherical mill until the split is smaller than $75 \mu$. The milled mass is placed in the dryer oven at a temperature of $105{ }^{\circ} \mathrm{C}$, where it stays for 3 hours in order to take of the humidity, then is placed in a desiccator for 30 minutes to cool down, and finally samples mixed and homogenized shall sieved, while the required amount for extraction should be weighted in analytical scales (Kimbrough, Wakakuwa 1989).

The preparation of water and sediment samples for the measurement of heavy metals is based on sample mineralization by using the EPA 3015A and 3051A methods (H.M. 1994).

For the determination of heavy metals in water and sediment, the following two measuring techniques were used: measurement technique with SAA-F and ICP-OES metering techniques, carried out in the KHMI environmental analysis laboratory and in the private laboratory "Agrovet" accredited by the Kosovo Accreditation Agency (Kadriu et al. 2017).

\section{RESULTS AND DISCUSSION}

During the experimental and research phase, it was determined the concentration of heavy metals in samples obtained at four sample sites $\left(\mathrm{U}_{1}, \mathrm{U}_{2}, \mathrm{U}_{3}\right.$ and $\left.\mathrm{U}_{4}\right)$, while sample site $U_{4}$, reflects the sample from waters of Ibër River samples was while the $U_{4}$ location reflects the sediment and sample. So, the analysis indicates the concentration of $\mathrm{Pb}, \mathrm{Zn}, \mathrm{Cd}, \mathrm{Cu}, \mathrm{Mn}, \mathrm{Sb}$ and $\mathrm{Hg}$. Results obtained from these analyzes are given in Tables 2 through 8 .

Table 2. Concentration of $\mathrm{Pb}$ in water and in sediments according to sample sites according to seasons of year

\begin{tabular}{|c|c|c|c|c|}
\hline $\mathrm{Pb}\left(\mathrm{mg} / \mathrm{dm}^{3}\right)$ in waters & $\mathrm{U}_{1}$ & $\mathrm{U}_{2}$ & $\mathrm{U}_{3}$ & $\mathrm{U}_{4}$ \\
\hline June & 0.002 & $<0.001$ & 0,54 & 0.06 \\
\hline July & $<0.05$ & $<0,05$ & $<0,05$ & $<0.05$ \\
\hline September & 0.003 & $<0.001$ & 0,558 & 0.074 \\
\hline November & $<0.05$ & $<0.05$ & 0,610 & $<0.05$ \\
\hline March & 0.004 & $<0.001$ & 0,584 & 0.088 \\
\hline Direc. 75/440EEC & 0.05 & 0.05 & 0,05 & 0,05 \\
\hline $\mathrm{Pb}(\mathrm{mg} / \mathrm{kg})$ in sediments & & & & 328.714 \\
\hline Direc. 86/278/EEC & & & & $50-300$ \\
\hline
\end{tabular}

The presence of heavy metals in the waters and sediments of the Ibër River was done from results obtained. Basic reference values were taken from the Directive 75/440/EEC 
on surface waters intended for the production of drinking water and sediment Directive 86/278/EEC relating to the protection of the environment, soil and water used in agriculture, has served.

The results obtained from the water analysis show clearly the increase of the concentration beyond the reference values of $\mathrm{Pb}$ at the $\mathrm{U}_{3}$ and $\mathrm{U}_{4}$ sites. Excessive of the reference values in $\mathrm{Pb}$ are also present in the river sediment at the $\mathrm{U}_{4}$ site.

Table 3. Concentration of $\mathrm{Zn}$ in water and in sediments according to sample sites according to seasons of year

\begin{tabular}{|l|c|c|c|c|}
\hline$Z n\left(m g / \mathrm{dm}^{3}\right)$ in waters & $\mathrm{U}_{1}$ & $\mathrm{U}_{2}$ & $\mathrm{U}_{3}$ & $\mathrm{U}_{4}$ \\
\hline Qershor & 0.044 & 0.098 & 0.118 & 0.278 \\
\hline Korrik & 0.02 & 0.093 & 2.1 & 0.275 \\
\hline Shtator & 0.046 & 0.102 & 0.896 & 0.314 \\
\hline Nentor & 0.013 & 0.338 & 0.613 & 0.241 \\
\hline Mars & 0.048 & 0.106 & 0.334 & 0.902 \\
\hline Direc. 75/440EEC & 1 & 1 & 1 & 1 \\
\hline \multicolumn{5}{|l|}{} \\
\hline Zn (mg/kg) in sediments & & & & 4297.6 \\
\hline Direc. 86/278/EEC & & & $150-300$ \\
\hline
\end{tabular}

Regarding the concentration of $\mathrm{Zn}$, its presence in $\mathrm{U}_{3}$ exceeds the recommended values, while in the sediment, at the $\mathrm{U}_{4}$ location, the presence of $\mathrm{Zn}$ exceeds the enormous reference value.

Table 4. Concentration of $\mathrm{Cd}$ in water and in sediments according to sample sites according to seasons of year

\begin{tabular}{|l|c|c|c|c|}
\hline $\mathrm{Cd}\left(\mathrm{mg} / \mathrm{dm}^{3}\right)$ in waters & $\mathrm{U}_{1}$ & $\mathrm{U}_{2}$ & $\mathrm{U}_{3}$ & $\mathrm{U}_{4}$ \\
\hline June & $<0.001$ & $<0.001$ & $<0.001$ & $<0.001$ \\
\hline July & $<0.005$ & $<0.005$ & $<0.005$ & $<0.005$ \\
\hline September & $<0.001$ & $<0.001$ & $<0.001$ & $<0.001$ \\
\hline November & $<0.005$ & $<0.005$ & $<0.005$ & $<0.005$ \\
\hline March & $<0.001$ & $<0.001$ & $<0.001$ & $<0.001$ \\
\hline Direc. 75/440EEC & 0.005 & 0.005 & 0.005 & 0.005 \\
\hline \multicolumn{5}{|l|}{} \\
\hline Cd $(\mathrm{mg} / \mathrm{kg})$ in sediments & & & 18.828 \\
\hline Direc. 86/278/EEC & & & $1-3$ \\
\hline
\end{tabular}

Contrary to other heavy metals, the presence of $\mathrm{Cd}$, in either of the locations did not encountered excessive values in water, while in sediment we have a significant overrun of these values. 
Table 5. Concentration of $\mathrm{Cu}$ in water and in sediments according to sample sites according to seasons of year

\begin{tabular}{|l|c|c|c|c|}
\hline $\mathrm{Cu}\left(\mathrm{mg} / \mathrm{dm}^{3}\right)$ in waters & $\mathrm{U}_{1}$ & $\mathrm{U}_{2}$ & $\mathrm{U}_{3}$ & $\mathrm{U}_{4}$ \\
\hline June & 0.002 & 0.003 & 0.006 & $<0.0004$ \\
\hline July & $<0.02$ & $<0.02$ & $<0.02$ & $<0.02$ \\
\hline September & 0.002 & 0.004 & 0.036 & 0.008 \\
\hline November & $<0.02$ & $<0.02$ & $<0.02$ & $<0.02$ \\
\hline March & 0.003 & 0.005 & 0.033 & 0.012 \\
\hline Direc. 75/440EEC & 0.02 & 0.02 & 0.02 & 0.02 \\
\hline \multicolumn{5}{|l|}{} \\
\hline Cu (mg/kg) in sediments & & & & 352.51 \\
\hline Direc. 86/278/EEC & & & $50-140$ \\
\hline
\end{tabular}

$\mathrm{Cu}$ over the recommended values is found at site $\mathrm{U}_{3}$, while in other locations the $\mathrm{Cu}$ concentration is within the reference values. In the sediment, at $\mathrm{U}_{4}$ sample site, the presence of $\mathrm{Cu}$ exceeds and reflects more than double the reference value.

Table 6. Concentration of $\mathrm{Mn}$ in water according to sample sites according to seasons of year

\begin{tabular}{|l|c|c|c|c|}
\hline $\mathrm{Mn}\left(\mathrm{mg} / \mathrm{dm}^{3}\right)$ in waters & $\mathrm{U}_{1}$ & $\mathrm{U}_{2}$ & $\mathrm{U}_{3}$ & $\mathrm{U}_{4}$ \\
\hline June & 0.111 & 0.044 & 1.224 & 0.063 \\
\hline July & 0.145 & 1.51 & 4.78 & 0.182 \\
\hline September & 0.125 & 0.049 & 1.342 & 0.071 \\
\hline November & 0.063 & 0.083 & 2.475 & 0.27 \\
\hline March & 0.138 & 0.063 & 1.551 & 0.08 \\
\hline Direc. 75/440EEC & 0.05 & 0.05 & 0.05 & 0.05 \\
\hline
\end{tabular}

Water analysis on Mn, indicates excess of referral values at all sample sites, but higher concentrations are encountered at site $U_{2}$ and $U_{3}$, while as far as sediment is concerned, the concentration of $\mathrm{Mn}$ has been below the detection level of measurement techniques.

Table 7. Concentration of $\mathrm{Sb}$ in water and in sediments according to sample sites according to seasons of year

\begin{tabular}{|l|c|c|c|c|}
\hline $\mathrm{Sb}\left(\mathrm{mg} / \mathrm{dm}^{3}\right)$ in waters & $\mathrm{U}_{1}$ & $\mathrm{U}_{2}$ & $\mathrm{U}_{3}$ & $\mathrm{U}_{4}$ \\
\hline June & 0.002 & 0.002 & 0.02 & 0.004 \\
\hline September & 0.002 & 0.003 & 0.002 & 0.002 \\
\hline March & 0.002 & 0.005 & 0.002 & 0.002 \\
\hline Direc. 75/440EEC & 0.001 & 0.001 & 0.001 & 0.001 \\
\hline \multicolumn{5}{|l|}{} \\
\hline Sb $(\mathrm{mg} / \mathrm{kg})$ in sediments & & & 105.125 \\
\hline Direc. 86/278/EEC & & & \\
\hline
\end{tabular}


The information obtained from the results, reflects the excess of $\mathrm{Sb}$ in water at all sites, where the presence of this metal is higher at the $U_{3}$ site, but to some extent the presence of $\mathrm{Sb}$ also in the sediment.

Table 8. Concentration of $\mathrm{Hg}$ in water and in sediments according to sample sites according to seasons of year

\begin{tabular}{|l|c|c|c|c|}
\hline $\mathrm{Hg}\left(\mathrm{mg} / \mathrm{dm}^{3}\right)$ in waters & $\mathrm{U}_{1}$ & $\mathrm{U}_{2}$ & $\mathrm{U}_{3}$ & $\mathrm{U}_{4}$ \\
\hline June & $<0.001$ & 0.0008 & $<0.001$ & 0.0004 \\
\hline September & $<0.001$ & 0.0008 & 0.005 & 0.0049 \\
\hline March & $<0.001$ & 0.0009 & 0.0056 & 0.0053 \\
\hline Direc. 75/440EEC & 0.001 & 0.001 & 0.001 & 0.001 \\
\hline \multicolumn{5}{|l|}{} \\
Hg (mg/kg) in sediments & & & & 0.052 \\
\hline Direc. 86/278/EEC & & & $1-1.5$ \\
\hline
\end{tabular}

Results obtained from water analyzes at the sites $U_{3}$ and $U_{4}$, reflects concentrations over the reference values with $\mathrm{Hg}$ as well in the Ibër River waters, while in the sediment at the U4 site, no exceed of allowed values have been observed.

\section{CONCLUSION}

Results obtained during the monitoring of these waters, at four sites, reflected the best the concentration of heavy metals such as $\mathrm{Pb}, \mathrm{Zn}, \mathrm{Cd}, \mathrm{Cu}, \mathrm{Mn}, \mathrm{Sb}$ and $\mathrm{Hg}$ in the river bed and in the Ibër river waters. Samples for analysis were obtained during the summer and winter season 2018/2019. Sample analyzes have confirmed that there is contamination of the Ibër River waters in water and in sediment with these heavy metals, with the exception of $\mathrm{Cd}$ which is not present in the water, but its presence in the sediment is evident.

At the end of this paper, we can conclude that the results obtained from the laboratory tests, based on reference values arising from Directive 75/440/EEC and Directive $86 / 278 / \mathrm{EEC}$, reflect that the potential source of contamination with metals heavy waters and sediment of the Ibër River, is the Kelmendi landfill.

Therefore, in order to avoid once and for all the pollution of the Ibër River metals, the intervention of the revitalization of this landfill is based on the EU standards as a necessary necessity for the responsible institutions of Kosovo.

\section{ACKNOWLEDGEMENTS}

I would like to thank all collegues having contributed to carry out the work presented in this article. 


\section{REFERENCES}

KADRIU S., MALOLLARI I., PULA-BEQIRI L., ALIU M., SADIKU M., BARUTI B., KELMENDI M., 2017, Presence of heavy metals in water and sediment of rivers Trepça and Sitnica, Journal of Environmental Protection and Ecology, 18 (1), 10-21.

KADRIU S., HOXHA B., PULA-BEQIRI L., ZEQIRI L., KELMENDI M., 2011, Water Pollution of the River Ibër with Heavy Metals from the Landfill Located in the Village Kelmend of Mitrovica, Journal of International Environmental Application and Science, 6 (2), 253-263.

CHINTAN PATHAK, HIREN C. MANDALIA, 2011, Impact of Environmental Pollution on Human Future, World Journal of Environmental Pollution, 1 (2), 8-10.

MALIK N., BISWAS A.K., QURESHI T.A., BORANA K., VIRHA R., 2010, Bioaccumulation of heavy metals in fish tissues of a freshwater lake of Bhopal, Environ. Monit. Assess., 160 (1-4), 267-276.

CHEHREGANI A., MALAYERI B.E., 2007, Removal of heavy metals by native accumulator plants, International Journal of Agriculture and Biology, 9 (3),462-465.

APHA, AWWA, WEF, 2005, Standard methods for the examination of water and wastewater, 21st ed., New York, American Public Health Association, p. 70.

GOLETIĆ Š., 2005, Teški metali u okolišu, Mašinski fakultet Zenica.

International Standard 17025: General Requirements for the Competence of Testing and Calibration Laboratories, 2005-05-15.

DAUVALTER V., ROGNERUD S., 2001, Heavy metal pollution in sediments of Pasvik River drainage, Chemosphere 42 (1), 9-18.

MACFARLANE G.B., BURCHETTT M.D., 2000, Cellular distribution of $\mathrm{Cu}, \mathrm{Pb}$, and $\mathrm{Zn}$ in the Grey Mangrove Avicemnia marina (Forsk.), Vierh. Aquatic Botanic, 68, 45-59.

H.M., EPA Method 3015, 1994, Microwave assisted acid digestion of aqueous samples and extracts, "Skip" Kingston, Duquesne University, Pittsburgh, PA USA, Final Version September.

KIMBROUGH D.E., WAKAKUWA J.R., 1989, Acid Digestion for Sediments, Sludges, Soils, and Solid wastes. A Proposed Alternative to EPA Sw 846 Method 3050, Environmental Science and Technology, Vol. 23, p. 898 . 